\title{
6. From Vietnam to Iraq: Negative trends in television war reporting
}

ABBSIHACI

In 1876, an American newspaperman with the US 7th Cavalry, Mark Kellogg, declared: 'I go with Custer, and will be at the death.' ${ }^{1}$ This overtly heroic pronouncement embodies what many still want to believe is the greatest role in journalism: to go up to the fight, to be with 'the boys', to expose yourself to risk, to get the story and the blood-soaked images, to vividly describe a world of strength and weakness, of courage under fire, of victory and defeat - and, quite possibly, to die. So culturally embedded has this idea become that it raises hopes among thousands of journalism students worldwide that they too might become that holiest of entities in the media pantheon, the television war correspondent. They may find they have left it too late. Accompanied by evolutionary technologies and breathtaking media change, TV war reporting has shifted from an independent style of filmed reportage to live pieces-to-camera from reporters who have little or nothing to say. In this article, I explore how this has come about; offer some views about the resulting negative impact on practitioners and the public; and explain why, in my opinion, our 'right to know' about warfare has been seriously eroded as a result.

Keywords: conflict reporting, embedded, television war reporting, war correspondents

\section{TONY MANIATY}

Australian Centre for Independent Journalism

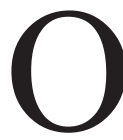

N 22nd December 1961, the first American serviceman was killed in Saigon. By April 1969 a staggering 543,000 US troops occupied South Vietnam, with calls from field commanders for even more. By 1975, 58,000 American troops had been sent home in body bags, and television had delivered the terrible reality of war to Western living rooms with an authenticity never seen before-or since. 
America's longest war, its greatest national rupture since the Civil War, and ultimately, its first-ever military defeat. And, yes, the first television war. Is there a nexus here? Conflict multiplied by TV coverage equals what? Did television lose the war for the Americans - and the Australians? Arguably not, but historians will debate that for centuries to come. What we know for certain is that television coverage of war after Vietnam would never be the same again.

To understand better this unfortunate outcome, it's important to look closely at how television news operated in the Vietnam conflict - the first, and perhaps the ultimate, television reality show. By 1965, the 'Big Three' U.S. networks - CBS, NBC and ABC-had established large bureaus in Saigon, staffed by experienced TV correspondents, cameramen (no women) and producers. The BBC was also there, and the Australian Broadcasting Commission (as it then was) maintained a bureau of one reporter working for both radio and television, with footage shot by visiting staff or freelancers, including, most famously, Australian Neil Davis. Competition between crews was intense, at times viscerally so.

These Saigon-based operations offered enormous freedom to operate independently of daily direction from 'head office' in New York, London or Sydney. This was an era of no emails, no internet, no text messaging; international phone calls were prohibitively expensive. Inter-office communication was by telex-which could be ignored with the often true excuse, 'We were upcountry, filming'. Journalistic independence was as much about movement as content. The Saigon-based news teams made their own decisions not only about what to film but also how to shape the story, based on their own news judgment.

\section{'Embedded' with Vietnamese society}

TV correspondents and crews were 'embedded' - not with the American military, but within Vietnamese society. News postings were usually a oneyear minimum, and three years in the Australian ABC's case. Many reporters had Vietnamese partners, lived in local neighbourhoods, ate local food; they absorbed the war's ups and downs. Crews in Vietnam had enormous freedom of mobility. To gain US military accreditation, the would-be war reporter needed only to present a letter of introduction from any outlet (a local TV station would do); this entitled crews to seats on 'any aircraft, anywhere' in 
the war zone, greatly expanding the range of story possibilities, and soldiers of all ranks from privates to generals could be interviewed, if they agreed, without supervision and uncensored, right there in the battlefield.

The chemical nature of film coverage had major implications. Firstly, cameras had only limited time-range, as little as three-minutes for a handheld Bell \& Howell; film shooting had to be tight, relevant to the narrative. Secondly, there were no processing facilities in Saigon; as a result, until the footage arrived a day or two later in Singapore, Bangkok, Tokyo or New York, producers had no real idea what they were getting, and they had no ability to re-direct crews to shoot the story again from a different angle. This gave battlefield TV crews enormous power (and responsibility as journalists). Thirdly, the 'footage' they shot could not be 'dubbed' in the field, copied to other networks through either informal or formal swapping arrangements as we might later with video and digital transfers. Networks in the field really were competing, each producing a unique story. And critically, throughout the war, there were no satellite transmission facilities in Saigon; a few major stories were sent out later in the conflict ex-Tokyo, at huge expense.

The footage may have been up to a week old, even older, but it told a story that viewers could understand and empathise with. And field correspondents and studio-based TV producers were not averse to highlighting casualties, including close-ups of the dead. As it happened, more of the horror of war was screened on television during the Vietnam War than in any conflict since; the reality of 'blood and gore' would be replaced, in both the Gulf War of 1991 and the Iraq War of 2003 and beyond, by relatively bloodless 'shock and awe'.

The result of these factors, added to an early style of TV news that emphasised the narrative 'story' over the assembled 'package' (the narrative 'story' now having shifted to current affairs television), meant that, whatever it lacked in live crosses, immediacy, high-end graphics and special effects, day-to-day coverage of the Vietnam war had a rare (and probably unrepeatable) degree of battlefield authenticity, narrative variety and independence of vision which audiences could sense, and often comprehend as medieval horror, and reacted to powerfully.

Two sequences in the war exemplified this. Vietnamese cameraman Vo Suu, working for NBC, filmed the arbitrary shooting of a Viet Cong suspect by South Vietnam's chief of police during the 1968 Tet offensive. The footage was shown on NBC Evening News 46 hours after it was filmed (Goot \& Tiffen, 1992, p. 117). 
Four years later, indelible images of a young Vietnamese girl, Kim Phuc, running naked towards the cameras, would haunt all efforts to find a solution to the war. NBC cameraman Le Phuc Dinh was among those who captured this searing moment, a surreal metaphor of the war's insanity. As Associated Press's last Saigon bureau chief George Esper later observed, 'People looked at it and said, "This war has got to end"' (quoted in Chong, 2000, p. vii).

In the annals of journalism, the television coverage of the Vietnam War occupies a proud place. Of course much of it was shaped by the usual handout mentality, by the mediocre efforts of crews happy to get some 'bang-bang' on film, but there was much too that was intensely and graphically observed, that did not buy the White House and the Pentagon line, that questioned harshly why America was in Vietnam, that helped to sharpen the domestic and international debate. Gradually those images began to stomp all over America's efforts in Vietnam, until it was beyond even the power of the President to reverse the reporting freedoms in place. Battlefield reverses, tactical blunders, casualties: all were screened on TV, and burned into the dispirited American soul.

That was the unique moment of Vietnam. By the time of the next major conflict, faced with the ugly prospect of live TV coverage from the battlefield and spooked by Vietnam, the Pentagon bluntly decreed the media would work with the military, or not work at all. The networks, touched by the magnitude of the offer, quickly fell into line. In The First Casualty, Philip Knightley refers to the 'aberration' of Vietnam, adding: 'The freedom given to correspondents there to go anywhere, see everything, and write what they liked is not going to be given again...' (2003, pp. 481-482).

\section{Glittering showcase}

According to legend, the Gulf War of 1991 was CNN's war. The conflict provided a glittering showcase of America's new global strength; gave TV news extraordinary live images of war, and stellar audience ratings; and diverted public attention from the less savoury, traditional business of killing the enemy. There were high hopes it would also terminally erase the spectre of Vietnam. Bob Simon of CBS told of encountering an officer who remembered him from Saigon and said, 'Hello, Bob, come back to lose this one for us, too?' (quoted in Ferrari, 2003, p. 169). What viewers saw bore no relation to grim battlefield realities. When Baghdad came under fire, claimed CNN's co-founder Reece Schonfeld, 
'the world had a front-row seat' (Schonfield, 2001, p. 329). Well, yes and no. Video vaporisation of targets at 3000 metres did mean you could watch annihilation and eat pizza at the same time; war and its televised coverage, it seemed, had caught up with postmodernism. As Douglas Kellner observed, 'These images literally took the TV viewers into a new cyberspace, a realm of experience with which many viewers were familiar through video and computer games, the special effects of Hollywood movies, and cyberpunk fiction' (Kellner, 1999, p. 216). For millions, it was spectacularly enjoyable, provided you didn't think too deeply about human beings being fried like chips. 'High technology rendered the weapons smart, and the medium deaf, dumb, and blind,' noted Bruce Cummings, who wondered, 'How can an open shutter see so little?' (Cummings, 1992, p. 2). The answer: most of the 1500 correspondents who descended on the Gulf were confined to Saudi Arabia, where all stories underwent a 'security review', 'unprecedented in the history of US warfare' (Kellner, 1992, pp. 80-81). No crews could report from frontline units, except in small press pools. (Given this degree of censorship, was it so surprising that Sky News, as the BBC's Martin Bell alleged, was reduced from 'Breaking News' to 'Breaking Rumour'? (Hoskings, 2004, pp. 48-49)) Enter the new breed of correspondent, the TV dish monkey. Tied to million-dollar technology, the reporters stood before a strategically located palm tree at the Dhahran International Hotel, doing stand-ups (pieces to camera) to go with carefullyvetted pool footage of military successes they had not remotely witnessed. This, Cummings reflected, was akin to 'covering a ghetto riot in Detroit from Chicago's O’Hare Hyatt Regency’ (p. 110). Given they were largely informed by pool handouts and agency copy and footage, what deep insights could be offered from Dhahran that could not be offered from, say, Baton Rouge, Louisiana, or Hobart, Tasmania? You were either there- or not.

The Balkan Wars that raged through the 1990s did little to stem this trend. Yes, there were pockets of outstanding television reportage, but again the dish monkeys were chained to their rooftops and forbidden by distant studio producers to move off-camera. No doubt many were troubled by the very same dilemma that plagued the legendary William Howard Russell of the London Times in Crimea a century and a half earlier: 'How was I to describe what I had not seen? Where to learn the facts for which they were waiting at home?' (see Knightley, 2003, pp. 1-17). 
The focus now was on 'going live'. The networks ramped up continuous 'live' coverage to show audiences 'we're there', proving their commitment to the story (and, not unimportantly, justifying to the bean counters the enormous financial outlays of placing crews in the war zone) by instantly and constantly flicking to a correspondent 'on location' for updates and opinions. For the BBC's Kate Adie, and other seasoned war correspondents, it pointed to a growing, disturbing syndrome - reporters who could not report because they were constantly called on to deliver live reports:

Increasingly, hacks were tethered to the satellite dish, always on hand to deliver the 'live spot', in a curious belief that rabbiting on live is a more relevant and informed kind of reporting; in reality, someone stuck next to a dish for hours on end is the last creature on earth to have learned anything new, and probably unaware of a corpse twenty yards away. (Adie, 2002, p. 415)

So began the modern syndrome of the 'war' correspondent who is nowhere near warfare, who never makes the mistake of claiming to be in the actual war, but who willingly allows the audience to believe otherwise, and indeed, wants them to believe otherwise. When intercut with Pentagon-supplied footage, and with the addition of a bullet-proof vest or jacket with military overtones, the illusion is complete. The pretence soon becomes the reality. Throw back to Vietnam: did 'war correspondents' stand before palms in the Philippines, reporting the battle for Khe Sanh?

\section{The march of technology}

Cut to the Iraq War, 2003. Three decades after Neil Davis filmed a North Vietnamese tank crushing the gates of the Presidential Palace in Saigon, CNN is upfront with U.S. tanks as they roll victorious into Baghdad. In television terms, much has changed since the mud-and-slime days of Vietnam. Film has gone the way of the cutlass too; the sky is criss-crossed with satellites; 24-hour dedicated news networks such as CNN, Sky, BBC World and Fox screen the war in endless image loops, in formulaic packages; the digitisation of content means that images can be shuttled between continents in seconds, cut-and-pasted and reformatted endlessly; and the coverage of conflict no longer conforms to the old, three-step proposition of observation, investigation, and explanation, but has transmuted into a surreal and near-seamless 
form of home entertainment. Mobile phones, sat-phones, text messaging and email mean communications are instantaneous from anywhere in the battlefield to virtually any city on earth; soldiers ring wives and girlfriends every night, exchange family photos. Technology has transformed not only the battlefield, but also the televised coverage of war - and, just as warfare is increasingly conducted from remote locations, often thousands of kilometers from the action, so live television coverage is run from distant headquarters. In 2003, this is trumpeted as 'the march of technology' rather than 'the march of journalism'.

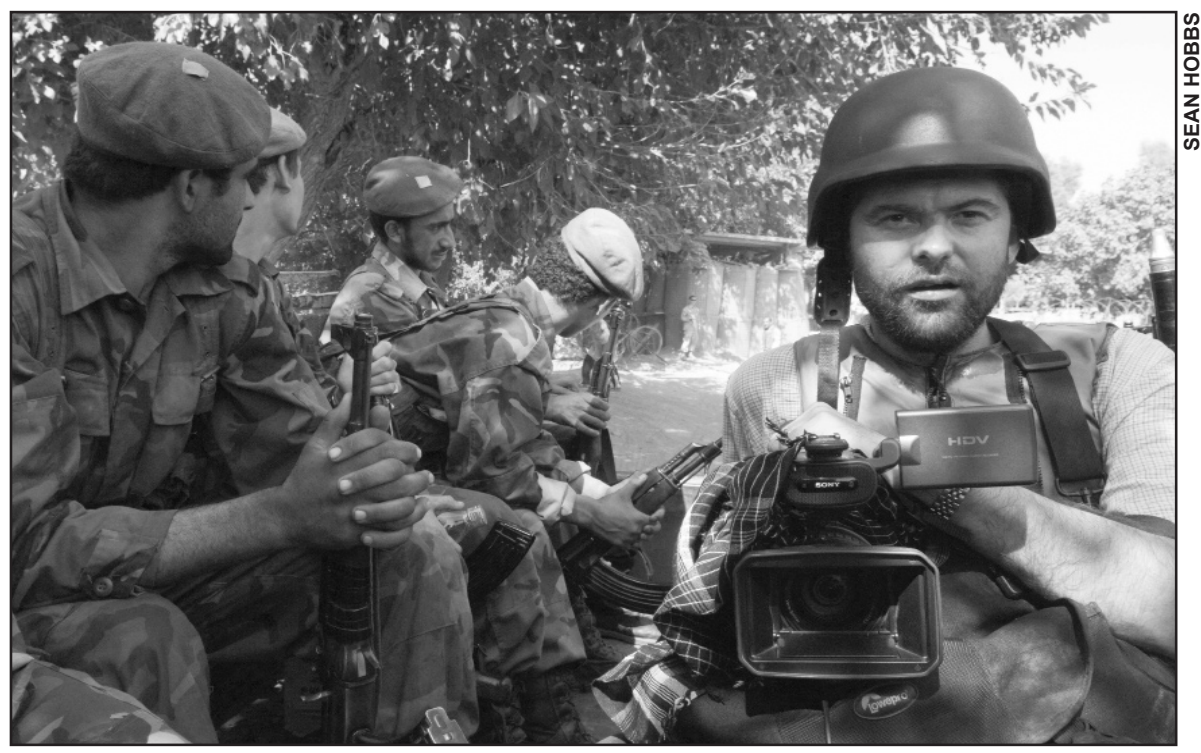

Figure 1: The technology has improved, but the risks do not go away. Freelancer John Martinkus, author of A Dirty Little War about East Timor, seen here on assignment for SBS Dateline in Kunar province, Afghanistan, in 2005, was kidnapped in Iraq - but he managed to escape. Others have not been so fortunate.

TV crews will be liberated from the theatrical stage of the five-star hotel, and 'embedded' in military units. One illusion will be replaced with another. 'This is going to be a weird war,' says Major Trey Gate, US Marines, Kuwait, 2003, 'We're going to live it and watch it at the same time' (quoted in Jackson, 2003, p. 15). And what is this particular illusion? TV crews will continue to report live, but on the move, kicking up dust, rolling forward 
with 'our boys' - yet almost never in harrowing close combat. Old-fashioned censorship will not be necessary: television crews, reliant on military transport and on surrounding troops for their survival, will do what they are told to. Eagle-eyed detachment will be rare, anodyne coverage far more likely. The industry mantra, 'If it bleeds, it leads,' will not apply-if it bleeds in Baghdad, it will be dropped. Later, in American Journalism Review, Lori Robertson will ask: 'Where were the bodies? It was a war in which hardly anyone seemed to die' (2004). Images of dead American soldiers, even in their coffins, will not be permitted. A study by the Project for Excellence in Journalism of 40.5 hours of coverage by ABC (America), CBS, NBC, CNN and Fox early in the conflict found about half the reports from 'embeds' showed combat action, but not one story depicted people hit by weapons (see Sharkey, 2003). Time magazine's Joe Klein accused the US networks of showing a 'PG-rated' war (cited in Sharkey). What television showed was not the multi-faceted horror of war but the palatable shorthand of war, in neat packages that audiences could watch without revulsion, bleaching the nightmare. Throughout the coverage, television witnessed another shiftfrom the industry's perspective, arguably the most momentous of all. Control of coverage moved rapidly from the battlefield crews to producers and programme editors 'back at base', often thousands of kilometres from the fighting. Advances in communications meant war reporters could no longer disappear 'upcountry' as they did in Vietnam-chasing leads, using their intuition, producing eye-witness accounts that offered viewers diversity, greater reportorial texture and a challenging range of viewpoints. Now, real-time connections and live crosses meant correspondents were perpetually on call, always 'in the loop' of news agency cover and military handouts, informed by what other networks were covering. White-shirted studio producers, most with no experience of conflict reporting, constantly fed via mobile phones new demands to field crews for updated stories. Critical decisions on which stories to cover, and how to cover them, and the power to make those decisions, shifted from the crews in the battlefield to producers at network headquarters. This process was regularly driven not by sound editorial judgments, but by networks watching competing networks on a bank of monitors and attempting to 'match' their coverage. If $\mathrm{CNN}$ has this angle, we must have it too. The field correspondent was duly informed, like a well-disciplined solider, of what was required. 
This pressure to 'match' the opposition's coverage resulted in increasingly narrowed and homogenised perspectives, a 'funnel vision' in which stories from the war zone began to look the same, often because they carried the same, endlessly syndicated shots. In many cases, only the reporter 'stand-ups' differentiated one television story of an event from another. The ABC's Eric Campbell found himself in remote and hostile places having, in his words, 'to fudge it by writing something to accompany pictures you haven't seen of events you didn't witness' (Campbell, 2005, p. 241). Is this what Ed Murrow had in mind when he observed in 1969, 'A satellite has no conscience'? (Murrow, 1969).Television news veteran Peter Manning, former head of ABC News and Australia's Seven Network News, asserted satellite technology had produced a 'dangerous trend' that gave studio-based news producers and programme editors immense power over war reporters:

... what you find is that any particular correspondent will be given the
news by the home foreign editor and told that... 'don't you know that
this and that has also happened? Well it has, and what I'd like you to
report is... what you said, but also in the context of what's come in
from these other places. And by the way I've just seen it on CNN and
I know you are out in the front line and you can't see it at the moment,
but that's what's happening, and I'd like you to report back on it.' Now
that kind of phenomenon I think is a basic corruption of the idea of the
independence of the foreign correspondents. (Manning, 2001)

Like many experienced war reporters, the BBC's Jeremy Bowen also expressed concern about these developments. 'One of the important things about being a foreign correspondent is to think for yourself and say to yourself: this is a story, this is what is going on. Sure, take feedback, have a conversation. That's what you are paid to do. But you are not being paid to be operated by remote control' (Bowen, J. interview with author, 19 September 2005).

Highlighting the dilemma, Eric Campbell at once treasured and bemoaned his satellite phone. 'Unlike my experience in other war zones, I was now in constant phone range. The new-model satellite phones were handheld and worked like mobile phones, so you didn't have to stop the car and set up a satellite dish to make a call. The downside was that the newsroom could reach you at any time of night or day' (Campbell, 2005, p. 322). 
To his credit, and at substantial personal risk, Campbell at least was in the war zone. An American dictionary defines a war correspondent as 'A journalist, reporter, or commentator assigned to report directly from a war or combat zone' (American Hertitage Dictionary, 2004). The key word here is not 'war', but 'directly'. Increasingly, correspondents were reporting at some distance from the killing zone. In many instances, rather than witnessing the 'shock and awe' of battle, television journalists were linked via satellite to a network producer elsewhere on the planet issuing instructions ('Don't go anywhere!') and demands for specific content with machine-gun regularity. Pressure to talk ad nauseam in repetitive live crosses about events often happening far from the reporter's field of vision increasingly skewed the war's coverage; so did the relentless calls for 'updates'. (Few had the nerve of crusty Sandy Gall, from Britain's ITN, who once informed a London producer: 'Sorry old boy, I don't do updates.' (New Statesman, 2007).) ABC News' head of international, Tony Hill, agreed that producers in Australia, not correspondents in the field, largely controlled the coverage. 'The overview was very much driven from Sydney, absolutely.' This created its own problems:

... it means you can put in more elements, make sure you have a more comprehensive overview. But it does mean the person on the ground doesn't have the ability to analyse or sort the material; firstly, [he] doesn't have the time [correspondents] used to have, and, secondly, [he] doesn't have the opportunity because the process is largely guided by subeditors and producers' vision and what's available back here. It's raised a lot of questions we have yet to answer properly. The technology has opened up new possibilities and at the same time shut down opportunities too. (Hill, T., interview with author, 8 June 2004)

The war officially lasted 800 hours, noted writer-filmmaker Mark Daniels, but generated 20,000 hours of video: 'That's three-and-a-half years of images to record one month of war' (Daniels, 2005). War and media overkill had merged in a perfect zenith, but the levels of comprehension had, if anything, been reduced by sheer volume of material, most of it live and repetitive. The new century offers what critic David Edwards terms 'the paradox of plenty'(cited in Swartz, 2003), where saturation media coverage has resulted in less, not more, understanding of what is really happening. (If you do not understand the Middle East crisis, observes the Glasgow University 
Media Group, it might be because you are watching it on TV news (Philo et al, 2003, p. 133).) The blurring of news and commentary, in which facts and careful quotes compete with opinion and supposition, only adds to the dilemma, while the maligned yet vital quest for something approximating a 'reality of events' is replaced by the supposedly more democratic option of 'choice'. Fox News proclaims, 'We report, you decide.' Increasingly, the industry reality is, 'We bombard, you go figure.'

\section{Conclusion}

While delivering an increased and generally welcome diversity of secondary media information outlets - niched cable channels, websites, blogs, SMS and so on-digital technology, has, in the case of mainstream electronic mediafree-to-air TV networks, and major cable channels such as CNN, Sky and BBC World - produced a far narrower and more homogenised coverage of events, limiting what mainstream audiences perceive as 'the reality of war'.

Digital technology may have changed the landscape dramatically, but the TV war reporter's primary mission in 2003 has changed little from the Vietnam days: to cover one-off events and to lock them into the context 'chain', assessing their immediate impact and deeper meaning. If that was the brief, the major networks failed dismally in the Iraq conflict, screening instead glimpses of spectacle drawn from 'embeds' along with the endless commentary of hotel-bound dish monkeys. In so doing, TV news coverage generally conspired against a more focused context; discouraged its natural offspring, serious debate; and in contradiction of the media's higher aims, harmed rather than helped the cause of democracy.

Long ago, the London Daily News' Edwin Godkin observed that the presence of William Russell as The Times' battlefield correspondent in the Crimea '...brought home to the War Office the fact that the public had something to say about the conduct of wars and that they are not the concern exclusively of sovereigns and statesmen' (Odgen, 1907, pp. 102-103). A century and a half later, that criticism also applies to mainstream media groups and their celebrity correspondents. ${ }^{2}$

Where does this leave the future of televised reporting of war? The fall of free-to-air TV news ratings continues apace, and, with it, the vast resources needed to deploy large teams into the battlefield to mount comprehensive, audience-gripping coverage. This relentless quest for real-time war drama 
has much to answer for, shifting increasingly precious resources away from more nuanced and informative reportage. For all its experience of televised war coverage, 'big' media struggles to sustain its claim to 'comprehensive coverage'. Increasingly, the survival of televised war reportage as a genre that can be rated highly as journalism appears to rest elsewhere-with the smaller-scale, independent output of video journalists emerging from the "new media' talent pool and operating well outside the established conventions of television reporting.

\section{Notes}

1. Quoted in Atkinson, R. (2004). In the Company of Soldiers: A Chronicle of Combat in Iraq (pp. 40-42). London: pp. 40-42.

2. Lawrence Godkin himself was a remarkable observer not only of warfare but of the media: he chided his lazier American colleagues in the Civil War for their 'wild ravings about the roaring of guns and the whizzing of the shells and the superhuman valour of the men...'(see Odgen, R., 1907, p. 205).

\section{References}

Adie, K. (2002). The kindness of strangers. London: Headline.

American Heritage Dictionary of the English Language. (2004). Fourth Edition. New York: Houghton Miffin. Retrieved on 23 April 2005, from: www.answers.com/ topic/war-correspondent?method $=5 \&$ linktext=war\% $\% 20$ correspondent

Campbell, E. (2005). Absurdistan. Sydney: HarperCollins

Chong, D. (2000)., The girl in the picture: The remarkable story of Vietnam's most famous casualty. London: Simon \& Schuster, p. vii.

Cummings, B. (1992). War and television. London: Verso.

Daniels, M. (2005). Script of documentary film Enemy image. Coproduction of Multimedia France Productions/France 2, in association with CBS, SBS TV Australia, YLE.

Ferrari, M. (Ed.). (2003). Reporting America at war: An oral history. New York: Hyperion, p. 169.

Hoskings, A. (2004). Televising war: From Vietnam to Iraq. London: Continuum. Jackson, S. (2003, April 3). 'War porn' obscures the gruesome truth, The Australian (Media), p. 5.

Kellner, D. (1992). The Persian gulf TV war. Boulder, Col.: Westview.

Kellner, D. (1999). From Vietnam to the gulf: Postmodern wars? In Bibby, M.(Ed.). The Vietnam war and postmodernity (pp. 216). Amherst: University of Massachusetts Press.

Knightley, P. (2003). The first casualty: The war correspondent as hero, propagandist and myth-maker from the Crimea to Iraq (3rd edition). London: Andre Deutsch. 
Manning, P. (2001, November 1). Interviewed on Media Report, ABC Radio National, Sydney. Transcript retrieved on 15 January 2006, at: www.abc.net.au/rn/talks/8.30/ mediarpt/stories/s407206.htm

Murrow, E. R. (1969). On receiving the 'Family of Man' Award. Quoted by Kendrick, A., Prime time. New York: Little Brown \& Co. Retrieved on 4 January 2006, from: at www.bartleby.com/63/14/8414.html

Odgen, R., (Ed.)(1907). The life and letters of Edwin Lawrence Godkin. Cited in Knightley, P. (2003). The first casualty: The war correspondent as hero, propagandist and myth-maker from the Crimea to Iraq (2nd edition). London: Andre Deutsch.

Philo, Greg; Gilmour, Alison; Gilmour, Maureen; Rust, Susanna; Gaskell, Etta; and West, Lucy; (Glasgow University Media Group). (2003). The Israeli-Palestinian conflict: TV news and public understanding. In Thussu, D. K. and Freedman, D., (Eds.)., War and the media. London: Sage Publications.

Robertson, L. (2004). Images of war. American Journalism Review, October/November. Retrieved on 7 May 2005, from: at www.ajr.org/article printable.asp?id=3759

Schonfeld, R. (2001). Me and Ted against the world: The unauthorised story of the founding of $C N N$. New York: HarperCollins.

Sharkey, J. (2003). The television war, American Journalism Review, May. Retrieved on 8 July 2004, from: www.ajr.org/Article.asp?id=2988

Schwartz, J. (2003). A cast of thousands: The media and the staging of Gulf war two. Australian Screen Studies, Issue 32, Spring. Retrieved on 6 June 2005, from: http://search.informit.com.au/documentSummary; $\mathrm{dn}=820340285551151$;res= E-LIBRARY

The New Statesman. (2007, August 16). Retrieved on 8 November 2007, from: www.newstatesman.com/200708160008

Tony Maniaty has spent more than 30 years as a broadcast journalist, author and media lecturer specialising in TV journalism and international affairs. His research interest is in conflict and risk reporting. He is a lecturer in journalism and director of the Australian Centre for Independent Journalism (ACIJ), University of Technology, Sydney.

tony.maniaty@uts.edu.au 